\title{
MEMBANGUN KARAKTER SISWA MELALUI PENGGUNAAN MEDIA PEMBELAJARAN SCRABBLE GAMES
}

\author{
Febri Fajar Pratama \\ Universitas Perjuangan Tasikmalaya \\ Jl. Peta No. 177, Kahuripan, Kec. Tawang, Tasikmalaya 46115 \\ Email: febripratama@unper.ac.id
}

\begin{abstract}
ABSTRAK
Pendidikan karakter merupakan hal yang sangat penting dalam menanamkan prilaku positif dalam diri siswa. Guru sebagai tenaga pendidik diharapkan dapat menginternalisasikan nilai-nilai karakter dalam diri siswa melalui inovasi pembelajaran di dalam kelas. Salah satu cara yang digunakan adalah dengan pengoptimalan penggunaan media melalui media pembelajaran berbasis permainan (games) yang mampu untuk mengubah kondisi kelas menjadi menyenangkan dengan tidak menghilangkan esensi dari tujuan pembelajaran itu sendiri. Tujuan penelitian ini adalah untuk mendeskripsikan secara mendalam tentang penggunaan media pembelajaran sebagai sarana pembentukan karakter melalui pendekatan kualitatif deskriptif. Pemilihan media scrabble ini didasarkan pada pengembangan model pembelajaran yang diterapkan di SMAN 5 Cimahi melalui permainan pada program one day one juz yang menggunakan media rangkai kata (ayat) untuk menanamkan karakter religius siswa. Berdasarkan hasil penelitian diperoleh kesimpulan bahwa penggunaan media pembelajaran yang kreatif dapat membentuk karakter siswa.
\end{abstract}

Kata Kunci: Pendidikan karakter; media pembelajaran; scrabble.

\begin{abstract}
Character education is very important in instilling positive behavior in students. Teachers as educators are expected to be able to internalize the values of character in students through innovative learning in the classroom. One of the method used is to optimize the use of media through game-based learning that are able to change classroom conditions into fun by not eliminating the essence of the learning objectives themselves. The purpose of this study is to describe in depth about the use of learning media as a means of character building through descriptive qualitative approach. The selection of scrabble media is based on the development of learning models applied at SMAN 5 Cimahi through games on the one day one juz program which uses a series of words (verses) to instill the religious character of students. Based on the results of the study concluded that the use of creative learning media can shape student character.
\end{abstract}

Keyword: Character education; learning media; scrabble.

\section{PENDAHULUAN}

Pendidikan karakter merupakan hal yang sangat penting dalam membentuk prilaku dan sikap siswa. Karakter dimaknai sebagai watak yang mengaplikasi pada tingkah laku 
seseorang atau individu yang berasal dari kebiasaan maupun cara pandang suatu nilai yang tertanam dalam diri individu tersebut. Namun, pada hakikatnya, karakter tidak tumbuh dan berkembang begitu saja dengan sendirinya, atau melekat pada diri seseorang secara otomatis. Karakter bisa tercipta tatkala seseorang itu melihat prilaku orang lain dalam lingkungannya, seperti dalam organisasi paling awal, yakni keluarga, dan lingkungan bergaul, sehingga mereka "mencerna" apa yang dicontohkan dan nilai yang ditanamkan yang kemudian mengakar pada prilaku serta tindakan yang dilakukan. Berbeda lingkungan, berbeda pula karakter yang ditampilkan. Berbeda keluarga, berbeda pula karakter yang ditanamkan. Nilai serta norma yang berlaku di suatu lingkungan tertentu akan membentuk pola prilaku khusus sesuai dengan keadaan di lingkungan tersebut. Maka, suatu karakter bisa dikatakan baik atau buruk tergantung dengan cara pandang dan bagaimana memaknai proses pembentukan karakter tersebut.

Secara umum, karakter yang dimiliki seseorang tidak bebas dan leluasa dapat di ekspresikan sesuai kehendak pribadi. Karena ada batasan-batasan tertentu sesuai dengan kaidah-kaidah yang berasal dari nilai, norma serta moral yang berkembang di dalam masyarakat. Dengan demikian, karakter haruslah sesuai dengan apa yang disepakati bersama sebagai sebuah konsensus dalam menilai sesuatu yang baik dan buruk berdasarkan budaya, adat, falsafah bangsa, dan yang paling penting adalah nilai agama. Sehingga, dapat dikatakan bahwa pendidikan karakter merupakan upaya untuk membentuk kepribadian manusia melalui proses untuk mengetahui kebaikan (knowing the good), mencintai kebaikan (loving the good), dan melakukan kebaikan (acting the good). Proses tersebut melibatkan tiga ranah yang meliputi: pengetahuan moral, perasan moral dan tindakan moral yang terimplementasi menjadi kebiasaan berpikir, hati, dan tindakan (Lickona, 1992:80). Senada dengan apa yang dikatakan oleh Lickona, Megawangi (2005) mengungkapkan bahwa pendidikan karakter merupakan usaha untuk mendidik anak-anak agar memiliki prilaku yang bijak dan baik untuk dipraktekan dalam kehidupan kesehariannya, sehingga mereka dapat memberikan kontribusi positif pada lingkungannya.

Pendidikan karakter sendiri sebenarnya secara eksplisit tertuang dalam peraturan perundang-undangan dan konstitusi kita. Dengan tegas dan jelas, pada Preambule UndangUndang Dasar Tahun 1945 dikatakan bahwa “...untuk membentuk suatu pemerintah Negara Indonesia melindungi segenap bangsa Indonesia dan seluruh tumpah darah Indonesia dan untuk memajukan kesejahteraan umum, mencerdaskan kehidupan bangsa, 
dan ikut melaksanakan ketertiban dunia..." yang kemudian dalam batang tubuh pasal 31 (3) dijelaskan bahwa "pemerintah mengusahakan dan menyelenggarakan suatu sistem pendidikan nasional, yang meningkatkan keimanan dan ketakwaan serta akhlak mulia dalam rangka mencerdaskan kehidupan bangsa..." Selanjutnya, apa yang telah dijelaskan dalam konsitusi dijabarkan kembali dalam Undang-Undang Sisdiknas No. 20 Thn. 2003 tentang tujuan nasional pendidikan Indonesia:

"Pendidikan nasional berfungsi mengembangkan kemampuan dan membentuk watak serta peradaban bangsa yang bermartabat dalam rangka mencerdaskan kehidupan bangsa, bertujuan untuk berkembangnya potensi peserta didik agar menjadi manusia yang beriman dan bertakwa kepada Tuhan Yang Maha Esa, berakhlak mulia, sehat, berilmu, cakap, kreatif, mandiri, dan menjadi warga negara yang demokratis serta bertanggung jawab."

Berdasarkan landasan dasar tersebut, jelaslah bahwa pendidikan karakter menjadi concern utama dalam mewujudkan pribadi siswa yang memiliki karakter sesuai dengan ideologi bangsa yang berdasarkan nilai-nilai ke-Tuhanan. Dalam mewujudkan akhlak mulia (baca: pendidikan karakter) sangat erat kaitannya dengan bagaimana proses pendidikan di lingkungan sekolah, meskipun sebenarnya implementasi pendidikan karakter tak hanya berpusat pada sekolah saja, tetapi keluarga dan juga lingkungan sosialnya. Namun, dari ketiga aspek tersebut yang kita kenal dengan istilah Tri Pusat Pendidikan, sekolah merupakan institusi yang memegang peranan sangat krusial dalam membentuk, mengembangkan dan juga menguatkan budi pekerti siswa, karena sebagian waktu siswa hampir setengahnya dihabiskan di sekolah.

Asriani, Sa'dijah, \& Akbar (2016) memandang pentingnya peranan dari pendidikan karakter di sekolah, yakni pendidikan pada dasarnya berusaha untuk mengembangkan kemampuan siswa sekaligus membentuk watak, sehingga pendidikan melalui proses pembelajaran dikelas bertujuan untuk merubah cara berpikir (kognitif), sikap (afektif) dan psikomotor (tindakan). Lickona juga mengungkapkan hal yang sama, bahwa tujuan utama dari pendidikan adalah untuk membantu para siswa menjadi pintar dan juga membantu mereka menjadi baik (Lickona, 2012). Namun, bukan tanpa masalah proses pembentukan karakter siswa di sekolah, dikatakan oleh Asriani, Sa'dijah, \& Akbar (2016) bahwa selama ini pendidikan karakter di sekolah masih berupa pengenalan norma dan nilai-nilai yang belum menginternalisasi dalam diri siswa, sehingga potensi prilaku menyimpang siswa masih marak terjadi saat ini. Sebagai solusi dari hal tersebut, tenaga pendidik dalam hal ini adalah guru, harus mampu melakukan revolusi pembelajaran di dalam kelas, dimana 
internalisasi nila-nilai yang diinginkan dapat tertanam dalam diri siswa. Salah satunya adalah dengan mengintegrasikan pendidikan karakter ke dalam setiap proses kegiatan belajar mengajar.

Hal tersebut dapat dilakukan dengan melakukan inovasi pembelajaran, penggunaan metode dan juga media yang dapat membentuk karakter siswa. Menurut Tafsir (dalam Asriani, Sa'dijah, \& Akbar, 2016) bahwa proses pengintegrasian pendidikan karakter dalam pembelajaran dapat dilakukan dengan beberapa cara, diantaranya: (a) Pengintegrasian materi pelajaran, (b) pengintegrasian proses, (c) pengintegrasian dalam memilih bahan ajar, (d) pengintegrasian dalam memilih media. Maka dari itu, penelitian ini bertujuan untuk mengulas lebih lanjut berkenaan dengan pengunaan media pembelajaran dalam menumbuhkan karakter siswa di sekolah. Adapun penelitian ini hasil pengembangan dari observasi langsung ke salah satu sekolah yang ada di kota Cimahi, yakni SMAN 5 Cimahi yang sudah sangat baik dalam menerapkan pola pendidikan karakter yang terintegrasi, tak hanya dari segi intrakulikuler, dan kokorikuler, namun juga melalui kegiatan ekstrakulikuler dimana salah satunya adalah kegiatan yang cukup baik dalam memupuk karakter religius siswa, yakni program one day one juz yang dikemas menarik melalui permainan. Berdasarkan hal tersebut, penulis tertarik untuk mengkaji tentang pembangunan karakter siswa melalui permainan, yakni media pembelajaran yang dikemas menarik dengan menggunakan scrabble.

\section{METODE PENELITIAN}

Penelitian ini menggunakan pendekatan kualitatif deskriptif yang bertujuan untuk menggambarkan secara mendalam dengan menginterpretasi makna dibalik realitas yang ada di lapangan (Suwarma, 2015; Batubara, 2017). Adapun dalam teknik pengumpulan data, penulis menggunakan metode observasi, studi dokumentasi, studi pustaka dan juga wawancara yang dilakukan pada setting lingkungan sekolah di SMAN 5 Cimahi guna melihat bagaimana implementasi pendidikan karakter yang ada di sekolah tersebut. Key person atau informan yang menjadi subjek penelitian yakni Guru PKn. Selanjutnya, peneliti menggunakan hasil observasi tersebut sebagai acuan dalam pembahasan tema yang berkenaan dengan media pembelajaran yang berbasis permainan (games) guna membentuk karakter siswa, dalam hal ini, permainan yang penulis pilih adalah scrabble. 


\section{HASIL DAN PEMBAHASAN}

\section{Implementasi Pendidikan Karakter di SMA 5 Cimahi}

Pendidikan karakter yang ada di SMAN 5 Cimahi tercermin dalam visi dan misi, yang mencakup 3 indikator, yakni: Bertakwa, Berprestasi dan Berwawasan Global (B3). Sehingga, dapat disimpulkan bahwa di SMAN 5 Cimahi, siswa diharapkan tidak hanya memiliki karakter yang unggul dalam hal akademik, namun juga berakhlak mulia, pun tidak ketinggalan juga dengan keterampilan abad 21 dimana salah satunya adalah pemanfaatan teknologi. Adapun strategi dalam pembentukan karakter yang dilakukan oleh SMAN 5 Cimahi yaitu:

1. Strategi mewujudkan manusia yang taat terhadap ajaran agama

1.1. Pada awal pelajaran (10 Menit) melaksanakan Tadarus Al Qur'an

1.2. Memberi kesempatan kepada peserta didik untuk melaksanakan ibadah shalat duha dan shalat dzuhur berjamaah

1.3. Memberikan waktu 15 menit bagi guru dan siswa diawal PBM untuk melaksankan kegiatan literasi

1.4. Memperingati hari-hari besar Islam

1.5. Menggunakan pakaian muslim pada setiap hari jum'at dan saat pembelajaran pendidikan agama islam

1.6. Menginfaqkan sebagian harta setiap hari jum'at

1.7. Membantu sesama yang terkena musibah

1.8. Membangun pembiasaan diri berbudi pekerti baik melalui program $3 \mathrm{~S}$ (Senyum, Sapa, Salam)

1.9. Membangunkan Pendidikan Karakter dengan membiasakan siswa selalu berdo'a dan menyanyikan lagu Indonesia Raya diawal pembelajaran atau lagu wajib nasional di akhir PBM.

2. Strategi mewujudkan warga sekolah yang unggul dalam prestasi akademik dan non akademik.

2.1. Merencanakan program pendidikan. Meningkatkan pembelajaran yang bermutu.

2.2. Meningkatkan sumber daya pendidikan dengan memberi kesempatan melanjutkan studi, mengikuti pelatihan, seminar dll.

2.3. Meningkatkan mutu pelajaran yang inovatif dan menyenangkan 
2.4. Menciptakan suasana kelas yang kompetetif dengan diberikan piagam penghargaan

2.5. Meningkatkan prestasi peserta didik dengan mengikuti olimpiade dan cerdas cermat

2.6. Membentuk penjurusan melalui seleksi akademik dan hasil psikotes, serta tes penempatan.

2.7. Melengkapi sarana dan prasarana yang menunjang prestasi akademik

2.8. Meningkatkan prestasi non akademik melalui ekstra kurikuler dalam bidang bahasa, olahraga, dan seni.

3. Strategi menguasai informasi teknologi

3.1. Meningkatkan mutu kompetensi pendidik melalui penguasaan IT

3.2. Menyelenggarakan pelatihan pembelajaran yang berbasis IT

3.3. Melengkapi sarana pendukung pembelajaran yang berbasis IT

3.4. Melakukan pengawas mutu (Quality Control) pendidik secara kontinu

3.5. Mengembangkan kreativitas dan, inovasi di bidang IT

4. Strategi Mewujudkan karakter mandiri

4.1. Membiasakan prilaku mandiri dalam berbagai kegiatan melalui pemberian tugas.

4.2. Membimbing dan membina karakter mandiri melalui layanan individual dan kelo mpok

4.3. Membina jiwa kepemimpinan melalui kegiatan OSIS

4.4. Membentukjiwa disiplin melalui upacara bendera.

4.5. Membentuk jiwa Cinta Tanah Air melalui Hari Rebo Nyunda

4.6. Membentuk jiwa siap menghadapi tantangan Era Globalalisasi melalui English Day setiap hari Kamis.

\section{Pembentukan Karakter melalui Permainan (games)}

Dalam membentuk karakter siswa, terutama dalam kegiatan belajar dan mengajar tentunya harus dibarengi dengan bagaimana guru sebagai seorang pengajar dan pendidik mampu untuk memberikan pelayanan terbaik bagi siswa. Sehingga, proses belajar menghasilkan interaksi optimal antara guru dan siswa yang menghasilkan perubahan prilaku akibat interaksi tersebut. Interaksi yang dimaksud adalah interaksi belajar mengajar yang bersifat interaktif dari berbagai komponen untuk mewujudkan tercapainya tujuan pembelajaran yang telah ditetapkan dalam perencanaan pembelajaran (Solihatin, 2012, hlm. 4-5). 
Interaksi belajar mengajar ini pada hakikatnya bermaksud mengantarkan siswa mencapai tujuan yang telah direncakanan sebelumnya. Dalam praktiknya, interaksi belajar mengajar melibatkan berbagai unsur yang dapat digambarkan dalam pola pembelajaran sebagai berikut:

\section{Bagan 1. Interaksi Belajar Mengajar}

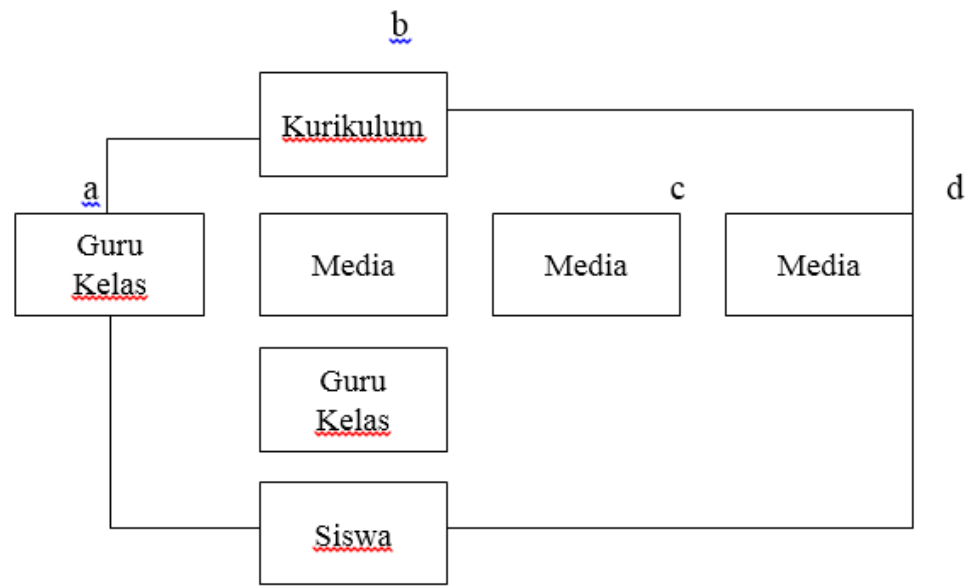

Sumber: Solihatin (2012, hlm. 8)

Pada bagan tersebut, dapat diketahui beberapa pola yakni : (a) pola interaksi guru di dalam kelas yang memegang kendali penuh atas berlangsungnya kegiatan belajar mengajar; (b) dalam pola ini guru kelas masih memegang kontrol hanya saja tidak mutlak, karena ia dibantu oleh sumber lain; (c) pada pola ini terdapat kontrol bersama, dimana sumber lain mengontrol penyajian informasi, sedang guru kelas mengontrol disiplin dan motivasi belajar siswa; (d) pola terakhir, sumber lain (media) mengontrol penyajian informasi secara lengkap, dan guru kelas berperan dalam merancang, mengembangkan, dan menilai media atau menyeleksi meida yang terintegrasi dengan tujuan pembelajaran, atau metode yang dipilih.

Dapat diketahui bahwa dalam pola tersebut, dapat terjadi interaksi baik yang searah (antara guru dan siswa) maupun dua arah/multi arah (guru, media, dan siswa/diskusi kelompok antar siswa). Sehingga dimungkinkan bahwa interaksi belajar dapat ditentukan sesuai dengan kebutuhan kurikulum yang dijalankan oleh guru. Saat ini, pola satu arah (metode konvensional) sudah tidak lagi menjadi pola utama dalam interaksi belajar, karena hal tersebut dirasa tidak cocok dalam membentuk afektif siswa, sehingga saat ini diutamakan pembelajaran dua arah dan juga multi arah yang dapat merangsang siswa untuk berpikir kritis, mandiri, kooperatif dan menciptakan suasana pembelajaran yang nyaman juga tidak membosankan. 
Salah satu hal yang dapat digunakan sebagai alat bantu dalam menciptakan suasana kondusif yang tidak membosankan adalah dengan penggunaan media. Dalam proses belajar mengajar kehadiran media mempunyai arti yang cukup penting. Karena dalam kegiatan tersebut ketidakjelasan bahan yang disampaikan dapat dibantu dengan menghadirkan media sebagai perantara (Djamarah \& Zain, 2002). Tentunya media ini sangat membantu guru dalam menyederhanakan materi pembelajaran yang dirasa rumit atau kompleks. Anak didik terkadang cepat merasa bosan dan kelelahan yang tidak dapat mereka hindari ketika berada di dalam kelas, karena dalam sehari saja, mereka harus belajar beberapa mata pelajaran yang tidak jarang menguras tenaga juga pikiran. Jika guru hanya menjelaskan di depan kelas tanpa ada proses pembelajaran yang menarik, yang mudah dicerna dan menyenangkan, maka akan terjadi kebosanan dan kurangnya konsentrasi siswa terhadap materi yang diajarkan. Djamarah \& Zain (2002) menyebutkan bahwa guru yang bijaksana seharusnya dapat menyadari kebosanan dan kelelahan yang menimpa siswa, sehingga guru harus mencari solusi atau jalan keluar, salah satunya yaitu dengan menghadirkan media sebagai alat bantu pengajaran guna mencapai tujuan yang telah ditetapkan sebelum pelaksanaan pengajaran.

Media pembelajaran yang memiliki nilai edukatif tinggi yang menyenangkan yakni dengan menggunakan permainan (games). Konsep permainan ini bisa beraneka ragam tergantung materi dan tujuan yang ingin diperoleh guru. Menurut Mutiah (dalam Nur, 2013) permainan dan juga bermain memiliki banyak fungsi bagi anak, yakni : dapat menumbuhkan kemampuan sosialisasi pada anak, sebagai sarana mengembangkan kemampuan dan potensi, permainan juga dapat mengembangkan potensi anak. Selain itu, menurut Sadiman (dalam Saadah \& Hidayah, 2013) menyebutkan beberapa kelebihan permainan sebagai media pendidikan sebagai berikut:

a. Permainan adalah sesuatu yang menyenangkan

b. Partisipasi aktif dari siswa untuk belajar melalui permainan.

c. Permainan dapat memberikan umpan balik langsung.

d. Penerapan konsep ataupun peran ke dalam situasi permainan

e. Permainan bersifat luwes.

Selain itu, Dikatakan oleh Nur (2013) bahwa permainan juga dapat membentuk prilaku atau karakter anak, selama permainan tersebut memuat nilai-nilai dan aspek tertentu yang menstimulus anak untuk mendapatkan nilai baru didalamnya. Misalnya, 
dalam suatu permainan, siswa bisa dituntut untuk kreatif, tumbuh rasa ingin tahu, disiplin, saling bekerjasama, dapat memecahkan masalah, atau bahkan memupuk rasa religius siswa. Hal tersebut dapat ditemui di SMAN 5 Cimahi pada program One Day One Juz (ODOJ) yang dapat dikemas menarik dan apik melalui metode permainan (games) rangkai kata (ayat) yang dibuat sendiri oleh siswa dan dimainkan secara bersama-sama, sehingga hal tersebut menjadi lebih menyenangkan dan terasa kebersamaannya, ada pula tutor yang membantu untuk mengarahkan dan memeriahkan program tersebut. Berikut contoh dari program One Day One Juz tersebut yang dilaksanakan setiap hari jum'at di SMAN 5 Cimahi:
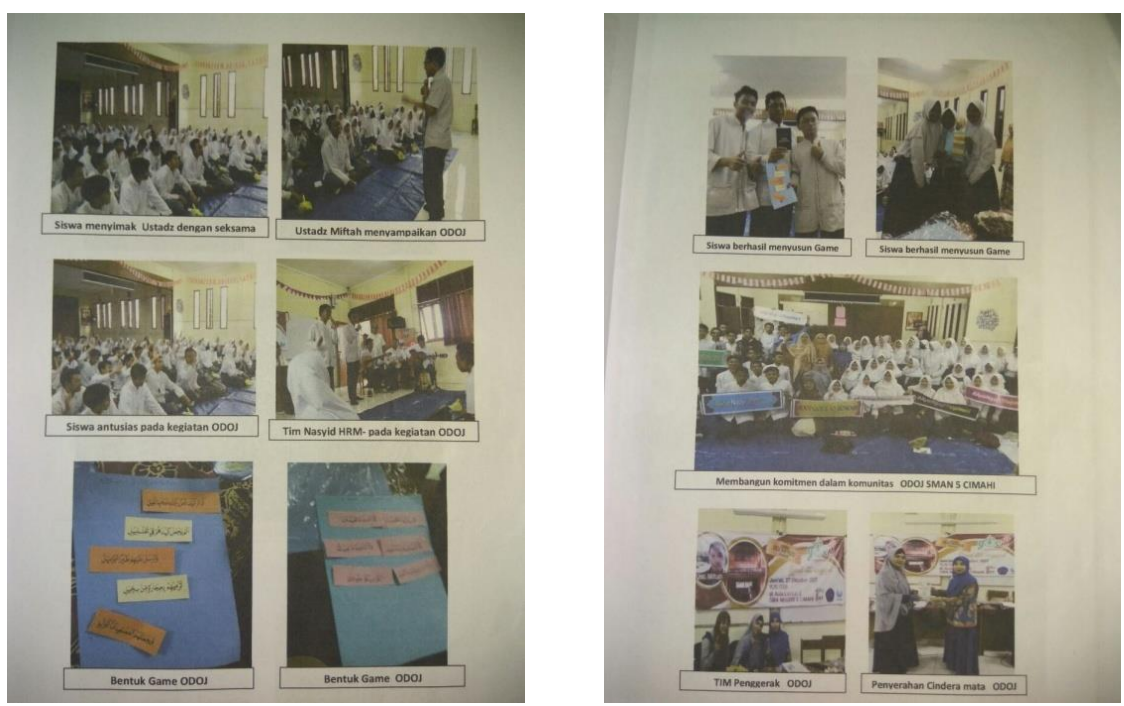

Gambar 1. Kegiatan ODOJ di SMAN 5 Cimahi

\section{Permainan Scrabble sebagai Media Pembelajaran dalam Membentuk Karakter Siswa}

Secara etimologi, scrabble berasal dari bahasa inggris yang berarti "bersungguhsungguh; bekerja keras; membanting tulang." Sedangkan secara terminologis, scrabble ini mengarah kepada suatu permainan yang melibatkan keterampilan dalam penguasaan kata secara acak (random). Permainan ini erat kaitannya dengan linguistik (kebahasaan) sehingga, banyak yang menggunakan permainan ini untuk meningkatkan kemampuan menguasai beberapa kata tertentu baik yang diacak, maupun merangkai kata dari kata yang sudah ada sebelumnya. Konsep permainan ini cukup sederhana, dimana aturan permainan hanyalah dengan menempelkan beberapa huruf diatas sebuah papan khusus yang terbagi kedalam beberapa kotak sebagai tempat untuk meletakkan huruf-huruf yang dimainkan oleh 2 orang atau lebih. 
Hinebaugh (dalam Saadah \& Hidayah, 2013) mengungkapkan bahwa scrabble merupakan salah satu jenis permainan yang dimanfaatkan dalam pembelajaran untuk menunjang kegiatan akademik siswa, dimana scrabble digunakan sebagai media dalam mengembangkan language skill (kemampuan berbahasa). Praat (dalam Saadah \& Hidayah, 2013) menjelaskan lebih rinci mengenai scrabble, yakni permainan yang dapat dimainkan oleh dua, tiga atau empat orang peserta dalam waktu tertentu. Permainan ini merupakan permainan menyusun kata di atas papan berkotak-kotak sejumlah 15 kolom dan 15 baris dengan menggunakan kepingan huruf sejumlah 100 tiles. Pemain menggunakan kepingan huruf untuk membentuk kata, baik secara mendatar maupun menurun, layaknya bermain teka-teki silang.

Berdasarkan penelitian yang dilakukan oleh Toma, Halpern \& Berger (2014) diketahui bahwa seseorang yang ahli dalam permainan scrabble, secara signifikan kemampuan kognitifnya lebih baik dibandingkan dengan orang biasa. Pengukuran secara visuospatial dan verbal abilities menunjukkan skor diatas rata-rata. Hal tersebut menunjukkan bahwa ternyata permainan scrabble dapat menjadi media untuk mengasah otak, dan juga untuk meningkatkan kemampuan kognitif. Dalam penelitian yang dilakukan Saadah \& Hidayah (2013) juga menunjukkan hasil yang hampir sama, di mana permainan scrabble berpengaruh cukup signifikan terhadap peningkatan kemampuan membaca anak disleksia (kesulitan membaca). Scrabble merupakan salah satu permainan board games yang tergolong ke dalam permainan kata untuk melatih kecerdasan dan kecepatan otak dalam mengolah kata-kata (Tirtouotomo, 2015). Selain itu, menurut Tirtoutomo, melalui permainan, guru dapat menerapkan pola pendidikan karakter dalam permainan tersebut agar dapat mengingternalisasi dalam diri siswa dengan cara yang menyenangkan. Berikut bentuk dari papan permainan scrabble yang terdiri dari beberapa kolom dan baris: 


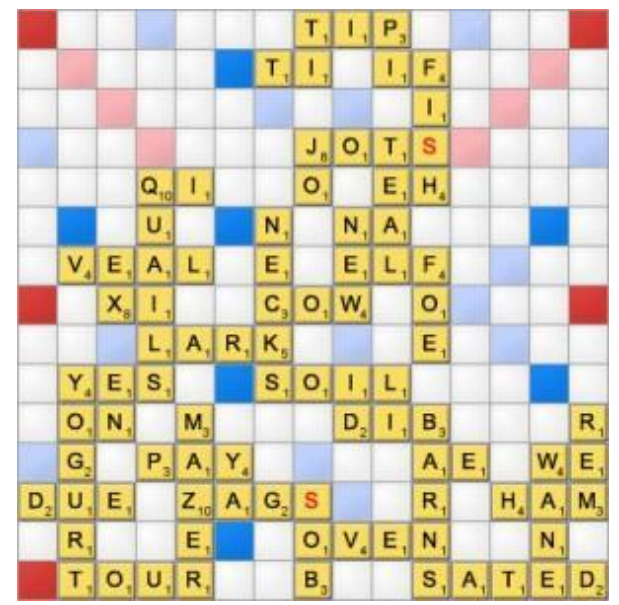

Gambar 2. Contoh Papan Permainan Scrabble Sumber: https://assets.kompasiana.com/statics/crawl/

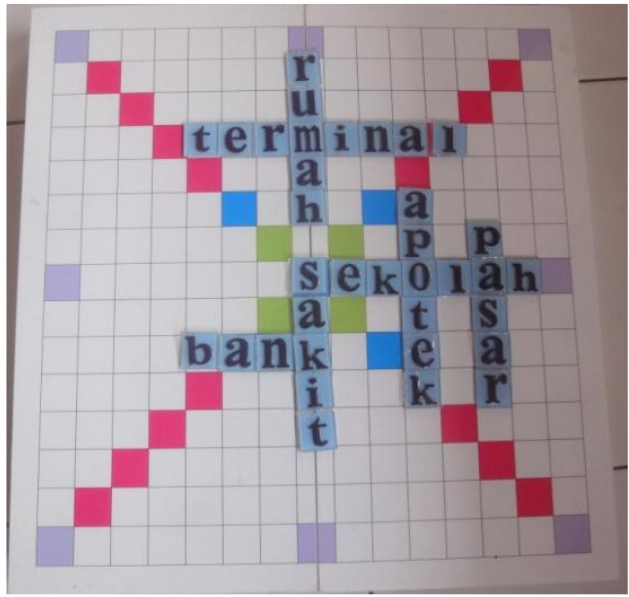

Gambar 3. Contoh Papan Permainan Scrabble (yang telah dimodifikasi) $\underline{\text { Aturan main: }}$

Sumber: Saadah \& Hidayah (2013)

Pemain yang terdiri dari 2 orang atau lebih harus mengeja kata dengan beberapa huruf yang telah disediakan, bagi pemain yang berhasil menyusun kata akan mendapatkan poin/skor, pemenang ditentukan dari skor yang paling tinggi. Permainan berakhir ketika tidak ada kata yang dapat disusun lagi, atau pemain telah menggunakan kesempatan terakhirnya merangkai sebuah kata atau sudah tidak ada kata lagi yang dapat dibuat.

Cara memainkan scrabble:

1. Permainan ini dimainkan oleh dua orang atau lebih;

2. Masing-masing pemain dibagikan tiles (kumpulan huruf secara acak) sebanyak 7 huruf;

3. Permainan dimulai dengan meletakkan satu kata ditengah papan permainan sebagai acuan untuk kata berikutnya; 
4. Poin diraih melalui kata-kata yang dapat dirangkai lewat kata yang sudah ada sebelumnya;

5. Masing-masing huruf memiliki poin tersendiri (biasanya huruf yang jarang digunakan memiliki poin tinggi, seperti $\mathrm{X}, \mathrm{W}, \mathrm{Z}$ );

6. Ada dua tiles kosong yang digunakan untuk membentuk kata, dan tiles tersebut bisa berupa huruf apa saja;

7. Ada beberapa kotak yang memiliki nilai bonus (Triple Word Score, Triple Letter Score, Double Word Score, dan Double Letter Score) sehingga, huruf yang menyentuh kotak tersebut dapat dikalikan sesuai dengan instruksi pada kotak tersebut, misalnya triple word score artinya huruf yang menyentuh kotak tersebut otomatis dikalikan 3 (nilai yang terdapat pada setiap huruf dijumlahkan kemudian dikalikan 3).

Permainan scrabble ini dapat disesuaikan dengan kebutuhan guru, bagaimana peraturan dan juga nilai yang diinginkan. Misalnya, setiap kata yang dihasilkan oleh masing-masing pemain, kemudian harus dicari makna nya untuk kemudian dicatat dalam buku masing-masing. Melalui permainan ini, tentunya pembelajaran akan terasa menyenangkan. Adapun karakter yang dapat dimiliki siswa melalui permainan ini antara lain: kemandirian (siswa tidak boleh bergantung kepada pemain lain), disiplin (siswa harus mematuhi peraturan yang sudah ditentukan), rasa ingin tahu (siswa menjadi penasaran dengan kata-kata yang dibentuk), kejujuran dan sportif (siswa tidak boleh memilih huruf) dan kerjasama (jika permainan disetting dalam bentuk kelompok).

\section{SIMPULAN}

Kegiatan belajar dan mengajar dalam kelas hendaknya tidak hanya dilakukan secara monoton, guru dapat melakukan inovasi dengan menggunakan media pembelajaran, salah satunya menerapkan permainan edukasi. Melalui media pembelajaran berbasis permainan, yakni scrabble, guru dapat menginternalisasikan nilai-nilai karakter dalam pribadi siswa dengan cara yang menyenangkan. Adapun nilai-nilai karakter yang dapat dicapai melalui permainan scrabble ini yaitu: kemandirian, disiplin, rasa ingin tahu, kejujuran dan sportifitas, serta kerjasama. 


\section{SARAN}

Peneliti berharap penelitian ini nantinya dapat dikembangkan lagi dan dikaji melalui beragam metode, terutama dalam menggali nilai-nilai karakter yang terkandung di dalam media pembelajaran berbasis permainan edukasi.

\section{DAFTAR PUSTAKA}

Asriani, Sa'dijah, \& Akbar. (2016). Pendidikan Karakter dalam Kegiatan Pembelajaran. Volume 2. Disampaikan dalam Prosiding Seminar Nasional Mahasiswa Kerjasama Direktorat Jenderal Guru dan Tenaga Kependidikan Kemendikbud, Pengembangan Profesionalisme Pendidik untuk Membangun Karakter Anak Bangsa, 19 November 2016. Malang: Universitas Negeri malang.

Batubara, Juliana. (2017). Paradigma Penelitian Kualitatif dan Filsafat Ilmu Pengetahuan dalam Konseling. Jurnal Fokus Konseling , Volume 3, No. 2 (2017), 95-107

Djamarah, Syaiful Bahri \& Zain. (2002). Strategi Belajar Mengajar. Jakarta: PT Rineka Cipta

Lickona, Thomas. (1992). Educating for character: How Our Schools Can Respect and Responsibility. New York: Bantam Books.

Lickona, Thomas. 2012. Character Matters: Persoalan Karakter. Jakarta: PT Bumi Aksara

Megawangi, Ratna. (2005). Pendidikan Karakter: Solusi Tepat Untuk Membangun Bangsa. Bogor: Indonesia Heritage Foundation

Muchtar, Al. Suwarma. (2015). Dasar Penelitian Kualitatif. Bandung: Gelar Pustaka Mandiri.

Nur, H. (2013). Membangun karakter anak melalui permainan anak tradisional. Jurnal Pendidikan Karakter, (1).

Republik Indonesia. (1945). Undang-Undang Dasar Negara Republik Indonesia Tahun 1945. Jakarta: Sekretariat Negara RI

Republik Indonesia. (2003). Undang-Undang No. 20 Tahun 2003 tentang Sistem Pendidikan Nasional. Jakarta: Sekretariat Negara RI

Roesdiono, Eddy. (2012). Main Scrabble untuk Mendongkrak Volume Kosa Kata. [tersedia online].https://www.kompasiana.com/eddyroesdiono/main-scrabble-untukmendongkrak-volume-kosakata_550baa18a333116e1c2e398b[diakses tanggal 30 Desember 2017]

Solihatin, Etin. (2012). Strategi Pembelajaran PPKn. Jakarta: PT Bumi Aksara

Tirtoutomo, S., Negara, I. N. S., \& Aryanto, H. (2015). Perancangan Media Board Game untuk Remaja Tentang Perilaku Baik dan Buruk. Jurnal DKV Adiwarna, 1(6), 12. 